\title{
ИНФОРМАЦИСКАТА СТРУКТУРА И СИНТАКСАТА НА ПРОСТАТА РЕЧЕНИЦА
}

\author{
Елени Бужаровска \\ Универзитет „Св. Кирил и Методиј“, Скопје \\ elenibuzarovska@t.mk
}

Во оваа статија подетално го разгледуваме влијанието на информациската структура (ИС) врз збороредот во стандардниот македонски јазик. За таа цел ги издвојуваме и ги опишуваме главните типови линеаризација на реченичните конституенти во простата реченица според нејзината комуникациска цел. Понудената класификација се заснова врз дискурсно-семантичката опозиција меѓу категоричките и тетичките искази. Речениците што функционираат како категорички искази типично предицираат некое својство за контекстуално познат субјектен референт. Затоа, тие се одликуваат со дводелна ИС тема - рема, што се одразува во прозодијата и во немаркираниот збороред, во кој тематскиот субјект му претходи на предикатот. За разлика од нив, тетичките искази воведуваат нов партиципант во дискурсот (презентатиски конструкции) или соопштуваат за нов настан. Таквата дискурсна функција им наметнува на овие реченици едноделна ИС во која целата реченица претставува рема, што често синтаксички се маркира со инверзија на субјектот и предикатот. Претпоставуваме дека ваквите конструкции содржат имплицитна локативна или темпорална определба (сценска тема). Но, нејзината реализација во иницијална реченична позиција повлекува одредени промени: дводелност на ИС и задолжителна субјектна инверзија.

Клучни зборови: категорички и тетички искази, инверзија, презентациски конструкции, сценска тема 


\title{
INFORMATION STRUCTURE AND WORD ORDER VARIATIONS
}

\author{
Eleni Bužarovska \\ Ss Cyril and Methodius University, Skopje \\ elenibuzarovska@t.mk
}

This paper aims to determine the effects of information structure (IS) on word order in standard Macedonian. We classify and describe the linearization patterns of simple sentences according to their communicative goal. The classification is based on the discourse-semantic distinction between categorical and thetic utterances. Sentences that function as categorical judgments typically predicate some property of a contextually known subject referent. Hence they have a binary topic-comment IS reflected in prosody and unmarked SV word order. In contrast, thetic utterances do not predicate a property but introduce a new participant into the discourse (presentative constructions) or report the occurrence of an event. This means that their IS consists only of a focus part, which tends to be marked by subject-predicate inversion. It is presumed that an implicit circumstantial locative or temporal adjunct serves as their stage topic. However, its realization in a sentence-initial position imposes a binary topic-comment IS in presentative sentences, triggering an obligatory subject-predicate inversion.

Keywords: categorical and thetic utterances, inversion, presentative constructions, stage topic 


\section{1 Вовед}

Во оваа статија подлабоко го разгледуваме влијанието на прагматиката врз синтаксата на простата реченица во македонскиот јазик. За таа цел ги опишуваме основните комуникациски типови реченици со немаркиран збороред и варијациите во збороредот предизвикани од промените во комуникациската цел на говорителот.

За немаркиран збороред на една проста реченица во македонскиот и во другите индоевропски јазици се смета збороредот субјект + предикат + објект (SVO). Таквиот збороред има семантичка мотивација со оглед на тенденцијата аргументите на транзитивниот глаголски предикат во реченичните позиции да се распоредуваат според т.н. природна хиерархија (Comrie 1989: 128): агенсот, односно вршителот на дејството да ја зафаќа субјектната, а трпителот - објектната позиција (1).

\section{Јана куйи книг̄а на саемой.}

Но, за разлика од јазиците во кои овие реченични функции се граматикализирале и не дозволуваат поголеми промени во линеаризација на реченичните конституенти (Rutherford 1989), збороредот во македонскиот јазик подлежи на влијание од прагматиката, пред сѐ, поради флективноста на глаголите.

Од прагматичка перспектива, речениците се реализираат во говорот како искази со кои искажуваме некое значење. Покрај пропозициското значење, кое се изразува преку лексичко-граматичка структура, речениците имаат специфично конверзациско значење. Тоа значење произлегува од комуникациската цел на говорителот и директно се одразува во информациската структура на исказот. Под информациска структура (скратено ИС) подразбираме распределба на информацијата во еден исказ според когнитивните принципи на нова и стара информација. ${ }^{1}$ Следејќи го принципот на природното процесирање на информацијата (Natural Information Flow), говорителот вообичаено го структурира исказот почнувајќи од познатата информација, на која се надоврзува новата (Comrie 1989: 127). „Старата“ информација, која е веќе дадена во текстот претходно, стои на почетокот на реченицата, а новата информација следува по неа, бидејќи е когнитивно потешка за процесирање (Halliday 1967). Тоа подразбира дека ИС на една реченица со немаркиран збороред (1) е тема - рема, каде што темата ${ }^{2}$ е конституент за кој станува збор во реченицата, а ремата е дел во кој се соопштува нешто за темата. Всушност, темата е пресупозијата (пресупонирана информација), а ремата е асерција, дел во кој се тврди нешто за темата. ИС на една реченица не мора да се совпаѓ со нејзината синтаксичка структура, но во немаркираниот збороред

\footnotetext{
${ }^{1}$ Во македонската предметна литература информациската структура е позната како функционална реченична перспектива (термин позајмен од Прашката школа) или актуелно расчленување на реченицата (Минова-Ѓуркова 1994: 208-211).

2 Терминот $\overline{ш е м а ~ г о ~ к о р и с т и м е ~ з а ~ п р е д м е т о т / л и ч н о с т а ~ з а ~ к о ј а ~ с т а н у в а ~ з б о р ~ в о ~ р е ч е н и ц а ~ с о ~ д в о д е л-~}$ на ИС. Темайа треба да се разликува од өискурснайа йема, која функционира на ниво на текст.
} 
тема е типично субјектот, а рема е предикатскиот израз. Темите тежнеат да се реализираат со определени референциски изрази, бидејќ г говорителот претпоставува дека слушателот може да го идентификува референтот на темата.

Во статијата сакаме да покажеме дека синтаксата на простата реченица пред сѐ се одредува од видот на ИС (дводелна наспроти едноделна), која, пак, зависи од комуникациската цел на исказот: дали говорителот предицира некое својство за темата, дали воведува нов учесник во дискурсот или информира за нова случка. За да ја утврдиме корелацијата меѓу информациската структура и синтаксата на простата реченица во македонскиот јазик, се фокусираме на три вида реченици претставени преку три комуникациски типови:

а. комуникациски деливи реченици во кои темата е дел од аргументско-предикатска структура (1);

б. комуникациски деливи реченици во кои темата посочува некоја околност (2);

в. комуникациски неделиви реченици без тема (3) .

Во рамките на првиот комуникациски тип (дводелна ИС тема - рема) се издвојуваат неколку варијации на немаркираниот збороред (SVO), предизвикани од потребата на говорителот да укаже кој дел од информацијата е поважен. Тоа често се постигнува со преместување на тој конституент (прилошка определба, директен/индиректен објект) во иницијална реченична позиција, која е когнитивно најзабележителна (1a). ${ }^{3}$

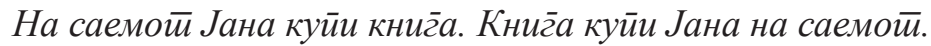

Во вториот комуникациски тип исказите имаат функција да воведат нов учесник или настан во дискурсот, ${ }^{4}$ сместувајќи го во определен простор или време. Соодветно, реченицата почнува со локативна или темпорална определба. Таквата „сценска“ тема не посочува на учесникот на настанот, туку на местото (или на времето) во кое се одвива настанот. Поради тоа, глаголските предикати во тие реченици типично означуваат постоење или појавување на новововедениот учесник во одредена локативно-темпорална рамка. Нивниот поприроден, немаркиран збороред е инверзија на субјект со непреодниот глагол (2), т.н. субјектна инверзија. ${ }^{5}$

Во каниеларија̄̄а / вчера gојое еяна жена.

Во третиот комуникациски тип спаѓаат исказите, чија комуникациска цел е да соопштат за случувањето на некој настан или да воведат нов учесник во говорот. Тие немаат тема; следствено, имаат едноделна ИС и не се разложуваат на информациски делови. Претпоставуваме дека тие се изведени од вториот комуникациски тип реченици (2) со нереализирана, но имплицитна сценска тема.

\footnotetext{
${ }^{3}$ Минова-Ѓ уркова (1994: 209) истакнува дека „актуелното расчленување на реченицата“ (односно ИС) зависи од контекстот, илустрирајќи го тоа со исти реченици што имаат различни ИС:

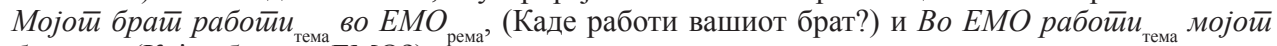
брай

${ }^{4}$ Терминот яискурс се однесува на кохерентен текст (односно негов дел) или говор.

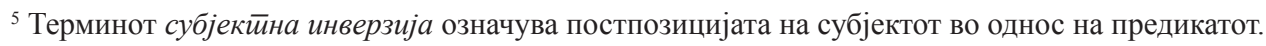


Дојяе еуна жена.

Во објаснувањето на варијациите во збороредот на реченици со дводелна ИС со информациска (1) и сценска тема (2), како и на речениците со едноделна ИС (3) се повикувавме, главно, на теориските ставови на Ламбрехт (Lambrecht 1994). Исто така, користиме некои поставки од деривацискиот пристап застапен во поновата функционално ориентирана литература: (a) дека маркираната линеаризација на реченицата се деривира од немаркираниот основен збороред; (б) дека е линеаризацијата нераскинливо поврзана со прозодијата, формирајќи линеарно-акцентна структура (Падучева 2016). Со промена на збороредот и на фразниот акцент во базичната реченица, се добива изведена комуникациски различна реченица (Циммерлинг 2016: 82).

Сметаме дека со линеарната деривација се објаснуваат варијациите во збороредот во состав на информациските дводелни реченици. Од базичната реченица од првиот комуникациски тип (а) се деривираат реченици со различна линеарно-акцентска структура, но со зачувана бинарна ИС. Деривациската релација постои и меѓу трите наведени комуникациски типови, но со промена на ИС. Варијациите во збороредот зависат и од други фактори: референцијалната семантика на изразот што функционира како тема, семантиката на глаголот и релациите на тематска кохерентност меѓу речениците.

\section{2 Теориска рамка}

Ламбрехт (Lambrecht 1994: 14) ја поврзува поделбата на дводелна и едноделна ИС со постоењето на два вида искази во јазикот: категорички (categorical) и тетички (thetic). Тие се разликуваат според комуникациската цел: категоричките искази тврдат нешто ново за ентитетот за кој станува збор (темата), додека тетичките искази воведуваат нов учесник или соопштуваат за случувањето на дискурсно нов настан (Sasse 2006). ${ }^{6}$

Категоричките искази даваат нова информација за темата и затоа имаат дводелна ИС тема - рема, ${ }^{7}$ како исказите во речениците (1) и (4).

\section{Мачкайа влезе во собайа.}

Во (1) се соопштува нова информација за Јана (купувањето на некоја книга), а во (4) за една одредена мачка (дека влегла во собата). Комуникациската цел на речениците се утврдува со прашањето Шӣо найрави Јана?/мачкайа? Одговорот е новата информација содржана во предикатскиот израз, кој се наоѓa во рематскиот дел од реченицата. Темата се однесува на главниот учесник на дејството, кој синтаксички се совпаѓа со субјектот. Референтите на Јана и

\footnotetext{
${ }_{6}^{6}$ Уште во 19 век во филозофијата се разграничуваат овој вид искази од категоричките искази (Lambrecht 1994: 138). Категоричките искази имаат две функции: го утврдуваат постоењето на субјектот и, истовремено, го потврдуваат или го негираат тоа што се искажува за него, додека тетичките искази само потврдуваат некој факт и затоа се логички поедноставни.

${ }^{7}$ Во англоамериканската предметна литература не се користат термините 'тема' и 'рема' (воведени од лингвистите на Прашката школа), туку ‘топик’ (пресупозиција) и ‘фокус или комент’ (асерција).
} 
мачкайа им се познати на соговорниците, бидејќи претставуваат дел од споделеното (пресупонираното) знаење меѓу говорителите.

Од тоа произлегува дека секој категорички исказ се дели на два информациски конституенти: тематски и рематски. Речениците со дводелна немаркирана ИС прозодиски се бележат со два реченични акценти: темата има нагорен акцент, додека ремата се истакнува со надолна интонација. Во рематскиот дел, зборот што го носи акцентот (акцентоген елемент) е познат како центар на ремата. Во горните примери - (1) и (4), тоа е прилошката определба во финалната реченична позиција. Таквата прозодија корелира синтаксички со немаркираниот збороред објаснет погоре.

Покрај категоричките искази, реализирани како реченици со дводелна ИС, јазикот располага со т.н. тетички искази. Тие се формализираат во реченици што не може да се поделат на информациски делови 'нова' и 'стара информација', бидејќи целата реченица претставува нова информација (Lambrecht 1994: 144). Соодветно, тие имаат едноделна ИС, што може да се провери со прашањето: Шӣо се случува/случи? Во овие искази фокусот е ставен на самиот настан. На пример, речениците во (5) одговараат на прашањето: Шӣо се

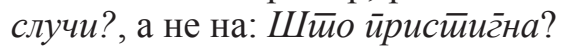

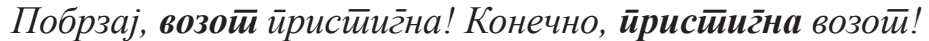

Според комуникациската функција, речениците со кои се реализираат овие искази се делат на два вида (Fiedler and Schwarz 2010): тие што воведуваат нов настан (реченици случки) и тие што воведуваат нов учесник во дискурсот (презентациски реченици). ${ }^{8}$

Прагматичката посебност на тетичките искази се маркира прозодиски со акцент на првиот реченичен конституент (кој претставува интонациски врв), но исто така, може и синтаксички, со обратна линеаризација, во која субјектот

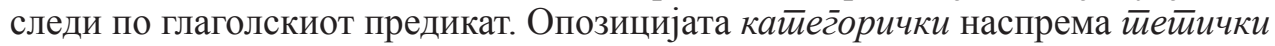
искази не е синтаксичка, туку прагматичка и е карактеристична за сите јазици. ${ }^{9}$ Понатаму ќе покажеме дека една иста реченица по форма и по содржина, може да функционира во јазикот и како тетички и како категорички исказ, зависно од комуникациската цел на говорителот.

\section{3 Комуникациски дводелни реченици со информациска тема}

Во овој дел ги разгледуваме речениците со дводелна ИС во кои темата е информациска, односно е дел од аргументско-предикатската структура. Од перспектива на текстот, таквата тема служи да ја поврзе реченицата со претходниот контекст. Затоа, линеарно-акценската структура на реченицата не мора да се совпаѓа со нејзината синтаксичка структура.

\footnotetext{
${ }^{8}$ Оригиналните термини за реченици случки се event-central thetics и entity-central thetics (Sasse 1987, Lambrecht 1994).

${ }_{9}^{9}$ Cace (Sasse 1987) во својата типолошка студија смета дека оваа опозиција е универзална и може различно да се манифестира: кај сите јазици таа се бележи со прозодија, а во јазиците со прагматички редослед дополнително се маркира со субјектна инверзија.
} 
Ремата може да го опфаќа целиот предикатски израз (т.н. широка рема) или само негов дел: вториот/третиот учесник или околноста во која се одвива дејството. Соодветно, разликуваме предикациска и аргументска рема. Следните исти реченици имаат различна поделба на тема и рема: во (6) ремата е предикациска, а во (7) - аргументска. Овој тип дводелна ИС е познат како инверзија на темата и ремата, каде што ремата во (7) врши функција на идентификација на учесникот на настанот (Падучева 2016: 43).

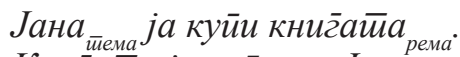

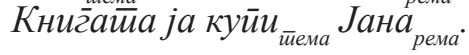

\section{1 Предикациска рема}

Веќе посочивме погоре дека постои корелација меѓу немаркираниот реченичен збороред (субјект, предикат, објект, прилошка определба) и немаркираната бинарна информациска структура. Тоа значи дека збороредот во реченицата претставена во (1) е детерминиран од дводелна ИС тема - рема, каде што субјектот на почетокот на реченицата, Јана, е тема, а ремата е целиот предикатски израз ја куйи книг̄aӣa на саемой. Тука се работи за т.н. предикациска рема, која соопштува што му се случило на референтот на темата на исказот.

Некои реченици може да почнуваат со информација за околноста на дејството, а не со субјектот. Таков иницијален конституент ја поставува рамката на познатите околности во кои се одвива дејството претставено во реченицата. Во предметната литература (на пр. Chafe 1976, Lambrecht 1994, ErteschikShir 1999, 2007), тој елемент се нарекува сценска тема (stage topic), кој се реализира како локативна или темпорална прилошка определба или прилог. Така (8) има две теми: една сценска (на саемоти/вчера) и една информациска $\left(\right.$ Јана), додека ремата е самиот предикатски израз (куйи книг̄a).$^{10}$

\section{На саемоӣ/вчера Јана куйи книг̄a.}

Истата прилошка определба во медијална или финална реченична позиција го модификува предикатскиот израз, лоцирајќи го настанот во време или место (1), додека во иницијалната позиција (8) определбата ја дава рамката на целата пропозиција изразена во реченицата. ${ }^{11}$ Веројатно разликата во функцијата на определбата потекнува од различниот информациски статус: во (1) таа е во рема, а во (8) е во позиција на тема.

\section{2 Аргументска рема}

\footnotetext{
10 За Дик (Dik 1989) разликата меѓу темата и сценската тема се должи, пред сѐ, на фактот што елементот кој функционира како сценска тема не е дел од предикатско-аргументска структура на пропозицијата.

11 За различната функција на определбата зависно од нејзината реченична позиција пишувале повеќе автори наведени кај Лахус (Lahousse 2007).
} 
Секое отклонување од немаркираната ИС влијае врз синтаксата на простата реченица предизвикувајќ́и промена во збороредот. Посилно нагласување на некој член на реченицата сигнализира дека е тој информациски фокус, а другите реченични конституенти носат позната пресупонирана информација. Овој поттип рема е познат како аргументска, бидејќи со неа најчесто се изделуваат учесниците или околноста на дејството. Во (9) субјектот е прозодиски и акцентски изделен: тој носи нова информација во дадената дискурсна ситуација дека токму Јана и никој друг го извршил дејството. Таквата прозодија означува т.н. контрастна рема (контрастен фокус), ${ }^{12}$ бидејќи презентирањето на некој реченичен конституент како нова информација креира значење на контраст. Останатиот дел од реченицата претставува позната информација за активноста на субјектниот референт во ремата.

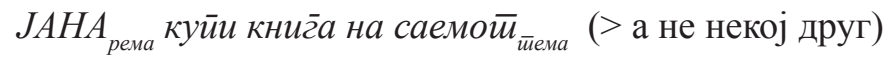

Новата информација може да биде само дел од предикатот, на пр. објектот на дејството. Одговорот на прашањето во (10): Шӣо куйи Јана е ремата книг̄a, а сите други делови на реченицата, вклучително и самиот глаголски предикат, се позната информација. И во (11) локативниот прилошки израз на саемой, кој е прозодиски истакнат, е во ремата, бидејќи одговара на прашањето: Kage Јана куйи книг̄a?

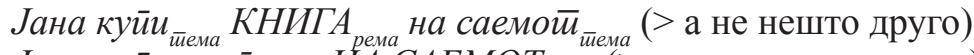

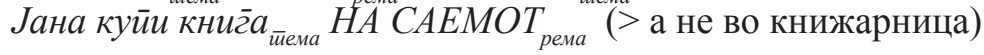

Прозодиски може да се издели и глаголот, ако говорителот сака да ја потврди вистинитоста на настанот врз фонот на познатата информација (12). Акцентогениот глагол создава верификациски контраст дека настанот, познат од претходниот контекст, навистина се случил (Падучева 2016: 47).

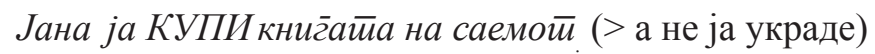

Акцентираните реченични елементи како информациски најважни може да се преместуваат во иницијалната реченична позиција. Таквата синтаксичка стратегија за обележување на ремата е позната како рематизација (или фокализација) како во (13). Иницијалната рема може да се појави за потребите на дискурсот и без контрастна семантика, на пр. Денес бев многуу вреgен: колайа ја измив, во банка ойияов, на Влаяо му се јавив...

КНИГА куйи Јана на саемоӣ. НА САЕМОТ Јана куйи книг̄a.

Екпресивната рематизација треба да се разликува од топикализацијата, во која ремата се преместува во позиција на тема: во (14) првата тема е Јана, а втората е определената именка книг̄a, бидејќи другиот дел од реченицата

\footnotetext{
${ }^{12}$ Истакнатиот збор се бележи со големи букви.
} 
предицира нешто за неа. Тоа може да се провери со изразот: Шӣо се оянесува gо (книг̄ā̄ $a) . .$.

\section{КНИГАТА Јана ја куӣи брзо (< Јана брзо ја куӣи книг̄айа)}

Следна варијација на немаркиран збороред е рецесија на тема (Падучева 2016: 37). Таа настанува како последица на линеарното преместување на глаголот, кој го носи реченичниот акцент, пред субјектот (15). Оваа стратегија се користи за постигнување на специфичен стилски ефект на продолжување на раскажувањето за темата во следната реченица. Всушност, темата се вметнува меѓу деловите на ремата: меѓу куйи и вториот учесник (директниот објект) книг̄aйa. Со тоа темата е во рецесија, односно следува по рематичниот глагол.

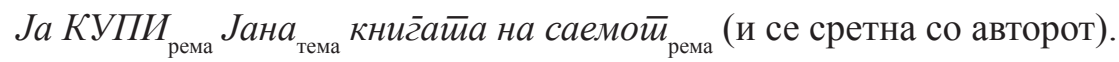

Рецесија на тема се среќава и кај речениците во кои нема втор учесник, односно кога глаголот е непреоден, па нема директен објект. Речениците со таква ИС обично се употребуваат како почеток на анегдоти или како наративна стратегија во приказни и случки.

ОТИШОЛ Мујо во Зоолошка...; ОТИШОЛ Мујо кај Хасо на г̄остии.... (www.pelister.org)

Во следната кратка текстуална целина (17) преовладува рецесија на тема во сите реченици, освен првата сложена реченица, која информира дека новововедениот, но идентификуван протагонист Пејо (познат од народните приказни), немал чевли и дека позајмил чевли за да се фати на оро. Понатаму следуваат реченици со рецесија на тема во транзитивна реченица (Го вияел чорбацијат̄а со чизмите), како и во нетранзитивните (Се навреяил Пејо, Ойишол Пејо).

(17) На еяен Велиг̄gен Пејо немал чевли за на оро, йа йозајмил еони чизми

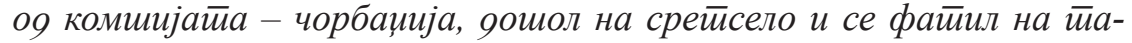

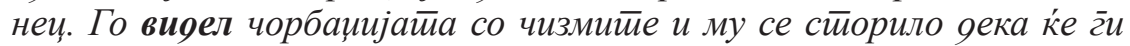
искине Пејо со иг̄рањейо и му рекол.... Се навреоил Пејо и веянаш

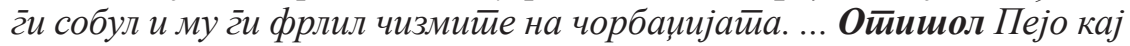

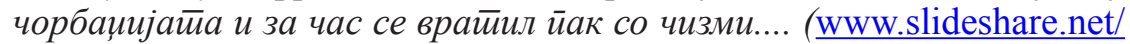
iskrapavlovska)

Некои честици се употребуваат пред рематскиот конституент за да укажат на ремата (Падучева 2016: 65). Така, неменливите зборови само и яури во (18) служат да го изделат субјектниот референт од множеството на пресупонирани учесници (сите други што купувале книги).

Оваа книг̄а само/оури и Јана ја куйи. 


\section{3 Прагматиката и синтаксата на темата}

Во овој дел ќе разгледаме како се вкрстуваат релациите меѓу формата и функцијата на конституентот што функционира како тема во реченицата со дводелна ИС. Ќе се обидеме да одговориме на прашањето зошто реченицата (19) е поприфатлива од (20).

Марко/комшијайа куйи нова кола.

Еоен комшија куйи нова кола.

Информацискиот и референцијалниот статус на главниот учесник на дејството влијае врз ИС на исказот. Учесникот јазично се кодира со т.н. референциски израз (именка, заменка), кој во немаркираниот збороред на синтаксичко ниво обично се совпаѓa со субјектот, а на информациско ниво - со темата. Темите ја формираат нишката што го поврзува текстот во кохерентна целина. Тие носат позната информација, врз која се надградува новата информација изнесена во ремата. Затоа темите тежнеат да бидат реализирани со определени референциски изрази што посочуваат познати референти, односно претставуваат „стара““ информација. Субјектниот референт во (19) означува лице познато на слушателот и затоа се реализира како лично име, кое посочува на единствен референт (Мар$\kappa o$ ) или со општа именка обележана со определен член (комиијайа). Членот е граматичко средство за означување дека слушателот може да го идентификува тој ентитет од множество исти ентитети (Lambrecht 1994: 52). Тоа значи дека личното име Марко и членуваната именка комиијайа сигнализираат дека референтите на овие именки посочуваат на идентификувани определени ентитети за разлика од неопределениот референцијален статус на субјектот во (20). Формата на референцискиот израз со кој јазично се кодира веќе воведен учесник зависи од неговото присуство во меморијата на говорителот (Lambrecht 1994: 22).

Колку почесто се споменува протагонистот во говорот/текстот толку повеќе е присутен во нашата меморија, па така истиот протагонист може да има активен, полуактивен и неактивен когнитивен статус (Givón 1983, Chafe 1987, Gundel et al. 1993). ${ }^{13}$ Поголемата прифатливост на (19) од (20) може да се објасни со тенденцијата темите да бидат когнитивно достапни за процесирање следејќи ја т.н. тематска хиерархија (Lambrecht 1994: 165). Тематската хиерархија ја изразува корелацијата меѓу когнитивната достапност на темата (типично, субјектниот референт) во нашата меморија и неговата реализација во јазикот, односно формата на тој референт.

Најдостапните, односно активните референти, се кодираат само со личната наставка на глаголот, полуактивните (достапните) со анафорска заменка (лична заменка во 3 лице), а неактивните (недостапните) со акцентиран именски израз (Lambrecht 1994: 109). ${ }^{14}$ Именката се однесува или на информациски нов референт, кој уште не е „зацврстен“ во меморијата на слушателот, или на референтот што е веќе е присутен во текстот (достапен), но треба да

\footnotetext{
${ }^{13}$ Ова е упростена верзија на хиерархијата. Ламбрехт разликува пет скаларни вредности: active $>$ accessible $>$ unused $>$ brand-new anchored $>$ brand-new unanchored.

14 За анафорските форми на субјектот во македонскиот јазик види Бужаровска и Митковска (2018).
} 
се активира во меморијата на слушателот, бидејќи е споменат пред повеќе реченици. Затоа неопределените именски синтагми се однесуваат на неактивни референти, а определените - на полуактивни и активни.

Да го илустрираме тоа со кратка секвенција од една народна приказна со тројца учесници: Итар Пејо, попот и алвата (обележани со подзнак). ${ }^{15}$

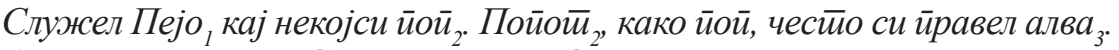
Арно ама, еgен оен Ø найравил йовеќе ойколку ийо можеле яа изеяай со Пеја, йа скоро йоловина $\varnothing_{3}$ им остианала. За gа не ја изеgе Пејо

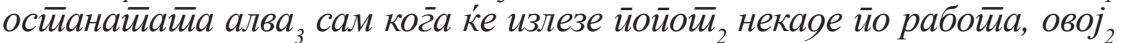
намислил яа г̄о зайлаши Пеја с со нешӣо... (https://makedonskijazik.mk/2)

Во горниот пример во првата реченица се воведува нов партиципант ( $\bar{u} о \bar{u})$ во дискурсот, односно во оваа кратка секвенција. Во втората се воведува третиот учесник, алвата. Во третата реченица тие имаат активен когнитивен статус, кој се бележи само со личната форма на глаголот (найравил, остианала). Бидејќи се веќе воведени, сите учесници може да бидат активни или полуактивни, но не нови. Во последната реченица првиот протагонист пак се посочува со име (Пејо), а вториот со показната заменка (овој) за да се избегне референцијалната двосмисленост меѓу двајцата учесници од машки род.

Најлесно се процесираат оние реченици чии теми се на врвот на хиерархијата. Во речениците со ИС тема - рема, најпогодни кандидати за тема се активните и познатите референти, ${ }^{16}$ а најнеприфатливи се неидентификуваните (непознати за слушателот) неактивни референти.

\section{4 Комуникациски дводелни реченици со сценска тема}

Овој вид реченици изразуваат тетички пропозиции, бидејќи воведуваат нов протагонист во текстот. Познати како презентациски, тие почнуваат со локативна прилошка определба, која ја зафаќа позицијата на тема. Тоа од своја страна наметнува дводелна ИС и субјектна инверзија на презентациските реченици, така што нивниот каноничен, немаркиран збороред е инвертиран (AdvVS).

\section{Во канцеларијайа/вчера gојgе еяна жена.}

Субјектната инверзија има специфична дискурсна функција, бидејќи преку неа се воведува нов учесник во текстот, кој претходно не е споменат или не се подразбира од контекстот (Downing and Locke 2006: 257, Prince 1992). Целта на воведувањето на новиот референт е да го потврди неговото присуство на одредена локација (Bentley et al. 2015: 48) како „сцена“ на која се наоѓa протагонистот, како на пр. во (23).

\footnotetext{
${ }^{15}$ Со подзнак ги бележиме кореферентните конституенти на реченицата, со Ø отсутниот референциски израз, кој се посочува со личната глаголска форма.

${ }^{16}$ Определената именка може да посочува и учесник што може да го идентификуваме од самата

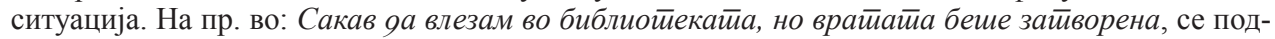
разбира дека се работи за вратата од библиотеката (Ward et al, 2002: 1368).
} 


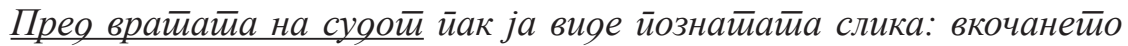
стиоеја на сииража овајца војници. Поо самайа згрраяа, неогрреана оя сонцетио, өремкаме осамен йајйон, со вирег̄найи йар јаяри, но мирни коњи. ${ }^{17}$

Семантиката на некои непреодни глаголски предикати е погодна за презентациската функција. Тоа се потврди во анализата на речениците од збирка есеи во која најдовме над стотина такви примери. ${ }^{18}$ Глаголите што се употребуваат за оваа комуникациска функција означуваат некаузални спонтани активности: појавување на новововедениот протагонист на сцената (се йојави, йроиуйи, изгрреа, никна, блесне, се иокаже, се г̃леgа, се слуша, се изгрраяи, се ойвори, се йроизвеgе и сл.), присуство или позиција на субјектниот референт на тоа место (се наог̈а, стиои, лежи, виси, остияне, йаяне, йече, се шири, се сйушйи, се крена и сл), но, исто така, и каузални дејства што изразуваат движење на протагонистот

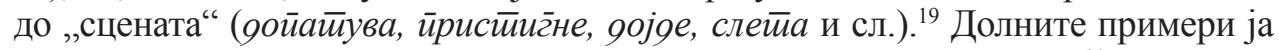
илустрираат презентациската функција на овие непреодни глаголи. ${ }^{20}$

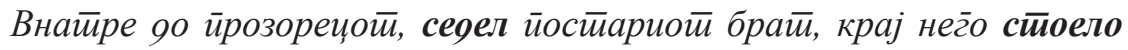
каяраво синче.

Ная Скойје лейаше кралскиой овог̆лав бел орел а йоя нег̄o се г̄руйи-

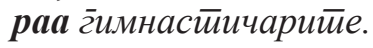

Одредени конвенционализирани изрази имаат таква презентациска функција за почнување на приказни: Си бил еgен човек..., Прея многуу гооянни си живеел еоен ияар....

\section{1 Референцијалниот статус на новововедениот учесник}

Во презентациските реченици со субјектна инверзија, протагонистите секогаш имаат нов информациски статус, бидејќи првпат се воведуваат во текстот. Но, нивниот референцијален статус може да биде различен. Така, во (26) Весна и еяна жена се дискурсно нови, но еяна жена означува непознато, а Весна познато лице за слушателот. Во следната реченица веќе воведениот протагонист станува тема за која се предицира нешто ново во ремата (донесе убави колачи).

Дојое еяна жена/Весна (и оонесе убави колачи).

Сепак, сметаме дека речениците со неопределени именски изрази или заменки во иницијална субјектна позиција (на пр.: Некој дојде.) може да се толкуваат и како искази со дводелна ИС (тема - рема), ако се акцентира и предикатскиот

\footnotetext{
${ }^{17}$ Примерот е од Абаџиев, Ѓ. (1961). Пустиина. Скопје: Македоника.

${ }^{18}$ Макеоонскиот̄ есеј. (2008). Џепаровски, И. (Уред.). Битола: Микена.

${ }^{19}$ Некаузалните во предметната литература се позанти како неакузативни, а каузалните, кои најчесто означуваат движење, како неергативни.

${ }^{20}$ Примерот (24) е од С. Стојчевски, а (25) од С. Јаневски во Макеgонскиой есеј.
} 
израз, односно ако реченицата има два реченични акценти. Тоа се потврдува во (27), во која истиот учесник станува тема во следната реченица со дводелна ИС.

Еоен човек/некој gојяе и ирамуваше за иеебе.

Покрај тоа, речениците со неопределени референти се специјализирале за одредени наративни стратегии: за почнување на анегдоти или необични случки (Бужаровска и др. 2019). Тие соопштуваат што направил еден нов и непознат референт фокусирајќи се на самата случка.

Еуен човек влезе во градски автобус во Белград и почна да пее хит од Здравко Чолиќ. (zase.mk)

Во словенските јазиците, во кои нема определен член за обележување на познат, активен референт и нема егзистенцијално има, само збороредот ја маркира разликата меѓу категоричките (29) и презентациските егзистенцијални реченици (30) со исто лексичко-граматичко значење. Долните примери се на руски јазик.

Книга на столе. 'Книг̄а̄̄а е на масайа.' На столе книга. 'Има еgна книга на масайа.'

\section{2 Сценска тема во презентациските реченици}

Во презентациските реченици присуството на локативна (или темпорална) определба ја „претвора“ информациската структура на реченицата во дводелна. Да го објасниме тоа преку примерот (31), кој има сценска тема за разлика од: Влезе Јана/еgна жена.

\section{Во собайа влезе Јана/еяна жена.}

Преместувањето на локативната определба по глаголот во (32) ја менува нејзината ИС, бидејќи определбата станува дел од ремата. Комуникациската цел на реченицата (32) е да соопшти што направил протагонистот на дејството, кој веќе бил споменат во претходниот текст. Затоа Јана е тема, а предикацискиот израз (влезе во собайа) е рема.

\section{Јана/еяна жена влезе во собайа.}

Речениците (31) и (32) не се разликуваат прозодиски: имаат по два реченични акценти, едниот на првиот, а другиот на последниот реченичен конституент, што зборува во прилог на тезата дека презентациските реченици со сценска тема имаат дводелна ИС. Но, ако отсуствува сценската тема (бидејќи е имплицитна), реченицата има едноделна ИС, како во: Влезе Јана. Тоа подразбира дека тетичките искази оформени како реченици со едноделна и дводелна ИС се меѓусебно поврзани. 
Поради стилски причини, центарот на ремата може да се премести на почетокот на реченицата, а сценската тема во крајната рематична позиција. Изведената структура е позната како суперпозиција на ремата. Според Падучева (2016: 49), тоа не ја менува едноделната ИС на реченицата и бројот на комуникациските делови останува ист. Таквата реторичка стратегија за привлекување на вниманието на читателите често се користи во новинарски наслови или за почеток на вестите (33), но, исто така, се среќава во уметничката литература.. ${ }^{21}$

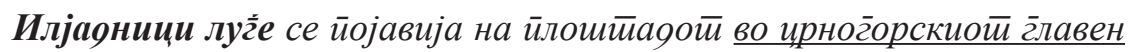
żpaq. (https://hi-in.facebook.com)

\section{5 Комуникациски едноделни реченици}

Како што наведовме во поглавјето 2, тетичките искази што соопштуваат за нови случки имаат едноделна ИС, бидејќи целиот исказ претставува нова информација. Тоа се одразува во прозодијата: тие имаат еден реченичен акцент, за разлика од категоричките, кои имаат два: еден акцент паѓа на темата, а друг на ремата (Sasse 1987: 529). И во двата типа има повеќе акцентогени единици.

Отсуството на тема кај тетичките реченици не значи дека тие немаат субјект и предикат на синтаксичко ниво. Тие не предицираат, односно не припишуваат некое својство на учесникот на дејството, бидејќи тој не е тема на ниво на ИС. Во речениците со кои се реализираат тетичките искази темата не е пресупонирана (или е отсутна) и затоа реченицата не се врзува со претходниот текст. По таа логика, безличните реченици (Врне, Се стиемни) и егзистенцијалните кон-

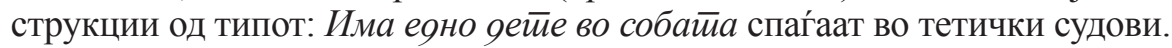

\section{1 Реченици случки}

Во ова поглавје се обработуваат вториот вид тетички судови, кои воведуваат нови настани во дискурсот и затоа ги нарекуваме реченици случки. Целата реченица е рема со едноделна ИС. Следејќи го Циммерлинг (2016: 83), разликуваме два поттипа: контекстуално независни и контекстуално зависни реченици случки.

Контекстуално независните искази изразуваат нови случки што не се врзани со претходниот контекст и затоа може да се употребуваат изолирано (34, $35)$. Во нив нема тема: не се соопштува за учесникот на настанот ( $\bar{u} е л е ф о н о \bar{u}$, мачкайа или Jана), туку за случката со тој протагонист. Овие реченици тежнеат кон инвертиран збороред (VS). Реченичниот акцент паѓа на првиот реченичен конституент (предикатскиот израз), а субјектот има надолен акцент. ${ }^{22}$

(34) Избег̄a мачкайа! (Што стана?)

(35) Дојое Јана. (Што има ново?)

\footnotetext{
${ }^{21}$ Иванова (2015: 104) дава пример од бугарска литература преведен на руски: Лек хладеи попъпли по кожата ѝ. Легкий холодок пополз по ее коже. 'Лесно студенило ѝ се ширеше по кожата.'

${ }^{22}$ Конституентот што го носи реченичниот акцент се бележи со зацрнети букви.
} 
Во следните примери се илустрираат таквите реченици од современата македонска проза. ${ }^{23}$

Гровна бомбайа и се слушаай само йискойници, машки лелейи.

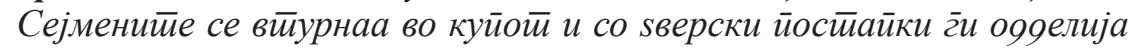

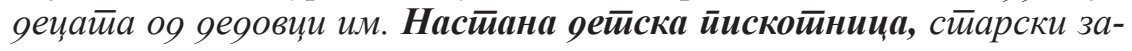
йомагағъа, йлачки, иицостии...

Во контекстуално зависните реченици случки новата информација е поврзана со ситуацискиот контекст. За разлика од контекстуално независните, тие немаат субјектна инверзија, но ја задржуваат истата прозодиска структура со акцент на првиот збор. Отсуството на инверзија имплицира каузално значење за објаснување на настанот и затоа тие се интерпретираат само во дадениот контекст.

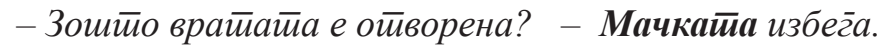

- Шӣо си йолку расйоложена? - Јана 9ојgе.

Разликата меѓу двата вида реченици случки може да се илустрира со реченици што имаат иста содржина, но формално се разликуваат по збороредот. Првата реченица (40) е контекстуално независна, бидејќи одговара на прашањето: Шӣо се случи?, а втората (41) е контекстуално зависна, затоа што претставува објаснување на говорителот зошто, на пример, дошол на работа пешки или со автобус.

(41) Колайа аи се расийа (и сега морам да...)

Иста разлика има меѓу речениците во (5): Побрзај, возой йристииёна! спаѓа во контекстуално зависните, бидејќи се дава причината за брзањето, додека: Конечно, йрисиииг̈на возой! претставува изолиран настан независен од претходниот контекст, па реченицата има субјектна инверзија. Но, мора да се истакне дека ваквиот збороред и во двата типа реченици е тенденција, а не правило.

Речениците случки може да преминат во категорички искази ако се промени нивната комуникациска цел. Кога соопштуваме нешто ново за учесникот на настанот, а не за самиот настан, реченицата добива дводелна ИС со два реченични акценти.

Јана gојяе (а не остана дома).

\section{2 Сценската тема во речениците случки}

Речениците случки може да содржат темпорална или локативна прилошка определба на почетокот на реченицата за да ја определи „сцената“ на која се одвива дејството.

\footnotetext{
${ }_{23}^{23}$ Андрееевски, П. М. (1980). Пиреј. Скопје: Мисла (пример 36); Сталев, Ѓ. (1958). Калеш Анг̇a. Скопје: Наша книга (пример 37).
} 


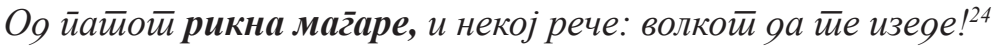

Речениците со сценска тема на почетокот на реченицата имаат дводелна информациска структура. Во (44) вчера или оо собайа е сценска тема, додека ремата е останатиот дел на реченицата, бидејќи одговара на прашањето: Шӣо се случи вчера?

\section{Вчера/оg собайа избег̄a мачкайа.}

Ако сценската тема не се реализира во реченицата, но се подразбира од претходниот контекст, се работи за имплицитна сценска тема (Erteschik-Shir 1999, Lahousse 2007, Teixeira 2016). На пр., во реченицата: Избег̄а мачкай

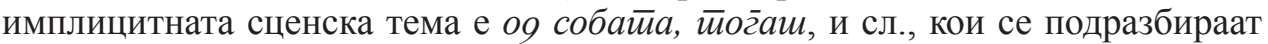
од самата ситуација: местото и моментот на настанот. Со преместувањето на определбата во финалната реченична позиција на рема, се менува ИС на реченицата. Таа станува комуникациски дводелна, со тема што е дел од предикатско-аргументската структура (мачкайа избег̄a).

\section{Мачкаӣа избег̄a вчера.}

Тетичките искази главно се употребуваат за дискурсни и стилски цели (Schwarz 2010): да воведат нов лик, да соопштат за неочекувана случка и на тој начин да ја прекинат тематската кохерентност на сегментот од текстот.

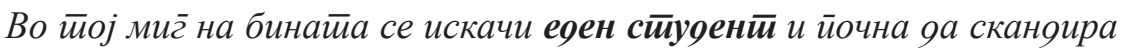

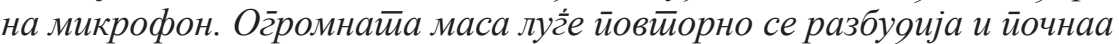
gа викаай во еоен гілас. ${ }^{25}$

Ако неопределениот именски израз што посочува на нововедениот референт ја зафаќа иницијалната позиција на тема во реченицата, настанува затемнување на разликата меѓу презентациските и речениците случки. Презентациските реченици без инверзија може да се толкуваат како реченици случки со посебна дискурсна функција: да воведат некој периферен настан (а не учесник). Таквиот настан придонесува за креирање на атмосферата што владее во некоја ситуација во моментот кога ја набљудува авторот.

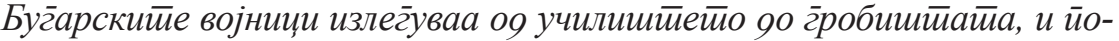

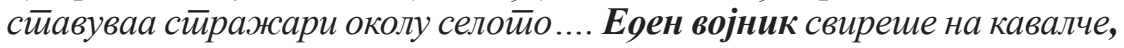
еоно загуубено йеле рикаше оя ӥреку река. А ная селойо само се накре-

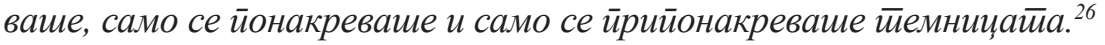

\footnotetext{
${ }^{24}$ Андрееевски, П.М. (1986). Пиреј. Скопје: Наша книга.

${ }^{25}$ Бужаровска, Р. (2018). Не ояам никаяе. Скопје: Или Или.

${ }^{26}$ Андрееевски, П.М. (1986). Пиреј. Скопје: Наша книга.
} 
И презентациските и речениците случки со субјектна инверзија често се комбинираат во истата секвенција за почнување на нарацијата. За илустрација го наведуваме почетокот на еден расказ. ${ }^{27}$

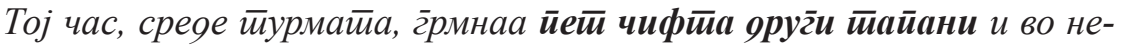
ботио лейна голлемо јайо зурли, возяухой йойло се залелеа, йочна

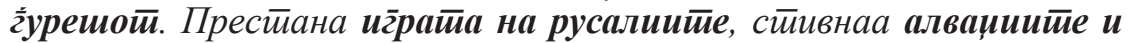

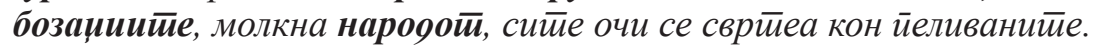

\section{6 Заклучок}

Во оваа статија покажавме дека збороредот во простата реченица во македонскиот јазик зависи од комуникацискиот тип на исказот што ја определува неговата информациска структура. Применетата класификација се заснова на опозицијата меѓу категорички и тетички искази. Трите изделени комуникациски типови се претставени со базична реченица која има ИС и немаркиран збороред карактеристичен за тој тип на ИС.

Речениците што функционираат како категорички искази имаат дводелна ИС, додека кај тетичките искази видот на ИС зависи од присуството на сценската тема. Презентациските реченици типично имаат сценска тема, па затоа се комуникациски дводелни, додека речениците случки се јавуваат со и без сценска тема. Отсуството на сценската тема ја замаглува разликата меѓу двата вида тетички реченици. Презентациските реченици преминуваат во категорички при преместување на „сценската“ прилошка определба во ремата. Речениците случки, од своја страна, можат да преминат во категорички при промена на комуникациска цел, што се сигнализира прозодиски. На пример, кога соопштуваме за самиот настан, а не што му се случило на учесникот на настанот, реченицата станува комуникациски едноделна. Така: Пейре ја скрши чашайа одговара на прашањето: Шйо найрави Пейре?, но истата реченица со извична интонација: Петире ја скрии чашайа! се толкува како реченица случка, бидејќи одговара на прашањето: Шӣо се случи?

\section{Библиографија}

Бужаровска, Е. и Митковска, Л. (2018). Реализација на анафорскиот субјект во македонскиот јазик. Современа филологијја, 1(2): 29-50.

Бужаровска, Е., Митковска, Л., Киркова-Наскова, А. (2019). Збороредот во простата реченица: инверзија на субјект и предикат. Современа филолог̃ија, 2 (2): 7-25.

Иванова, Е. Ю. (2015). Артиклевая маркиранность имменых групп как средство оформления коммуникативных стретегий говорящего в болгарском языке. Во Е. А. Лютикова, А. В. Циммерлинг, М. Б. Коношенко (ред.). Типология морфоситаксичских параметров, 90-114. Московский педагогический государственный университет: Москва.

Минова-Гууркова, Л. (1994). Синйакса на макеяонскиой сиианоаряен јазик. Скопје: Радинг. Падучева, Е. (2016). Коммуникативная структура и линейно-акцентные преобразования предложения. Во А. В. Циммерлинг, Е. А. Лютикова (ред.). Архитектура клаузы в параметрических моделях, 25-75. Москва: Языки славянской культуры.

\footnotetext{
${ }^{27}$ Манчев, В. Касиус Клеј и ќелавиот̄ змеј (http://makedonija.rastko.net/delo)
} 
Циммерлинг, А.В. (2016). Линейно-акцентная грамматика и коммуникативно нерасчлененные предложения в русском языке. Во А. В. Циммерлинг, Е. А. Лютикова (ред.). Архитектура клаузы в параметрических моделях, 76-103. Москва: Языки славянской культуры.

Bentley, D., Ciconte, F. M. and Cruschina S. (2015). Locatives in Romance dialects of Italy. Oxford: Oxford University Press.

Comrie, B. (1989). Language Universals and Linguistic Typology. Chicago: University of Chicago Press.

Chafe, W. L. (1976). Givenness, contrastiveness, definiteness, subjects, topics, and point of view. In C. N. Li (ed.). Subject and topic, 27-55. New York: New York Academic Press.

Comrie, B. (1989). Language Universals and Language Typology. Oxford: Blackwell.

Dik, S. C. (1989). The theory of functional grammar. Dordrecht: Foris Publications.

Erteschik-Shir, N. (1999). Focus structure and scope. Grammar of focus. In G. Rebuschi and L. Tuller (eds.). 119-150. Amsterdam: John Benjamins.

Erteschik-Shir, N. (2007). Information Structure: The Syntax-Discourse Interface. Oxford: Oxford University Press.

Downing, A. and Locke, P. (2006). English Grammar: A University Course. New York: Routledge.

Fiedler, I. and Schwarz, A. (2010). Introduction. In I. Fiedler and A. Schwarz (eds.). The expression of information structure: A documentation of its diversity across Africa, 7-9. Amsterdam: John Benjamins.

Givón, T. (1983). Topic continuity and word-order pragmatics in Ute. In T. Givón (ed.). Topic continuity in discourse, 145-195. Amsterdam: John Benjamins.

Gundel, J. K., Hedberg, N. and Zacharski, R. (1993). Cognitive Status and the Form of Referring Expressions in Discourse. Language, 2: 274-307.

Halliday, K. A. M. (1967). Notes on Transitivity and Theme in English. Journal of Linguistics, 3 (1): 37-81.

Lahousse, K. (2007). Implicit stage topics. A case study in French. Discours 1:1-23.

Lambrecht, K. (1994). Information structure and sentence form: topic, focus, and the mental representation of discourse referents. Cambridge: Cambridge University Press.

Prince, E. P. (1992). The ZPG letter: Subjects, definiteness, and information-status. In W. C. Mann and S. A. Thompson (eds.). Discourse Description: Diverse linguistic analyses of a fund-raising text, 295-326. Amsterdam: John Benjamins.

Runge, S. E. (2006). A Discourse-Functional Description of Participant Reference in Biblical Hebrew Narrative. PhD dissertation. University of Stellenbosch.

Rutherford, W. E. (1989). Interlanguage and pragmatic word order. In S. M. Gass and J. Schachter (eds.), Linguistic perspectives in second language acquisition, 163-182. Cambridge: Cambridge University Press.

Sasse, H-J. (1987). The Thetic/Categorial Distinction Revisited. Linguistics, 25: 511-580.

Sasse, H-J. (2006). Theticity. In G. Bernini and M. L. Schwarz (eds.), Pragmatic Organization of Discourse in the Languages of Europe, 255-308. Berlin: de Gruyter.

Schwarz, A. (2010). Discourse principles in grammar: The thetic/categorical dichotomy. In: Proceedings of the Tropics of the Imagination Conference, 2 November 2009, James Cook University, Cairns.

Teixeira, J. (2016). Locative Inversion and Stage Topics: A Cross-Linguistic Study. Discours, 19: 1-28.

Ward, G., Birner, B. J. and Huddleston, R. (2002). Information packaging. In Huddleston, R. and G.K. Pullum, The Cambridge Grammar of the English Language, 1363-1447. Cambridge: Cambridge University Press. 